\title{
MODEL STRATEGI PENGELOLAAN RUMAH ADAT BANJAR DI TELUK SELONG ULU1
}

\section{THE MODEL OF MANAGEMENT STRATEGY ON BANJARESE TRADITIONAL HOUSE AREAS IN TELUK SELONG ULU}

\author{
Hartatik \\ BalaiArkeologi Banjarmasin, Jl. Gotong Royong II, RT 03/06 Banjarbaru 70711, Kalimantan Selatan, email: \\ tati_balar@yahoo.com; tatitatibalar@gmail.com
}

\begin{abstract}
Abstrak. Rumah adat Banjar tipe Bubungan Tinggi dan Gajah Baliku di Teluk Selong Ulu, Kalimantan Selatan mempunyai bentuk dan bahan yang masih asli serta nilai penting bagi sejarah dan ilmu pengetahuan. Untuk kepentingan pariwisata, pemerintah membuat taman dan halaman parkir konblok beton dengan mengurung lahan rawa di depan dan samping rumah adat. Tulisan ini bertujuan untuk mengidentifikasi dampak pengelolaan dan membuat model pengelolaan kawasan rumah adat di Teluk Selong Ulu. Penelitian dilakukan dengan menggunakan metode kualitatif.Teknik pengumpulan data dilakukan dengan pengamatan langsung dan wawancara mendalam. Untuk membuat model pengelolaan dilakukan dengan teknik Participatory Rural Apprasial (PRA), kemudian dianalisis dengan menggunakan analisis SWOT.Hasil penelitian menunjukkan, bahwa pengembangan kawasan rumah adat telah menimbulkan dampak sosial yang meresahkan.Model pengelolaan dibuat dengan memperhatikan zonasi cagar budaya, melibatkan multi stakeholder baik pemerintah maupun masyarakat yang terkoordinir dan dilakukan secara berkelanjutan.Disimpulkan bahwa dengan strategi pengelolaan yang didasarkan pada prinsip pengelolaan sumber daya arkeologi dan kearifan lokal, maka kawasan rumah adat Banjar dapat dikembangkan dan dimanfaatkan optimal sebagai ikon dan kebanggaan budaya lokal.
\end{abstract}

Kata kunci : pengelolaan, sumber daya budaya, zonasi, Telok Selong Ulu, Kalimantan Selatan

\begin{abstract}
The Banjarese traditional buildings such as Bubungan Tinggi and Gajah Baliku in Teluk Selong Ulu, South Kalimantan have the authenticity of the form and material, and the values of historical and knowledge. Government created a garden and parking lot with concrete floor by swamp land reclamation in front and side of the traditional houses for tourism benefit,. This paper aims to identify the impact of current management, and makes new applicable management model of traditional house area in Teluk SelongUlu. The study was conducted by qualitative methods. Data were collected by direct observation and in-depth interviews. The making of applicable management model is using Participatory Rural Appraisal (PRA), and analyzing by SWOT. The results show that the development of the traditional house area has a social impact, disturbing surrounding people. The applicable management model is made by paying attention on cultural heritage zoning and involving multiple stakeholders, both government and society, which are coordinated and carried out in a sustainable manner. It is concluded that the strategy is based on the principle of archaeological resources and local knowledge, so the area of Banjarese traditional house can be developed and used optimally as an icon and pride of the local culture.
\end{abstract}

Keywords : management, cultural heritage, zoning, Telok Selong Ulu, South Kalimantan

\footnotetext{
${ }^{1}$ Tulisan ini merupakan bagian dari Tesis pada Program Studi Pengelolaan Sumber Daya Alam dan Lingkungan Pascasarjana Universitas Lambung Mangkurat Banjarbaru tahun 2014.
} 


\section{PENDAHULUAN}

Rumah adat Banjar merupakan salah satu sumber daya budaya yang masih tersisa di Kalimantan Selatan. Rumah orang Banjar berbentuk panggung, karena menyesuaikan dengan daerah rawa pasang surut yang cenderung basah. Identitas rumah Banjar mulai muncul sejak masa Kerajaan Banjar diperintah oleh Panembahan Sulaiman yang beristana di Karang Intan, sekitar tahun 1800 . Ada juga yang berpendapat bahwa rumah Banjar sudah ada sejak awal Kerajaan Banjar, yaitu pada masa Sultan Suriansyah pada pertengahan abad ke16. Rumah adat Bubungan Tinggi di Sungai Jingah, Banjarmasin merupakan rumah tertua yang surat segel izin pembuatannya dikeluarkan oleh Pemerintah Belanda pada tahun 1871. Rumah Banjar pada awalnya berupa bubungan tinggi tanpa anjung (ruangan di kanan kiri ruang induk, mirip sayap), kemudian ditambahkan anjung yang digunakan untuk kamar tidur. Atapnya berbentuk pelana yang menjulang tinggi ke langit, maka disebut rumah Bubungan Tinggi. Ada pula yang menyebutnya rumah baanjung karena mempunyai anjung di kanan kirinya (Saleh 1980/1981: 5-11).

Menurut Syamsiar Seman dan Irhamna (2006: 7-87), ada 11 tipe rumah adat Banjar, yaitu: Bubungan Tinggi, Gajah Baliku, Gajah Manyusu, Balai Laki, Balai Bini, Palimasan, Palimbangan, Anjung Surung, Tadah Alas, Joglo, dan Lanting. Kecuali rumah lanting, sepuluh rumah lainnya merupakan rumah panggung. Di Teluk Selong terdapat dua buah rumah adat Banjar yang berusia lebih dari 130 tahun dan kini menjadi cagar budaya yang dilindungi oleh undang-undang. Berbagai upaya pemugaran sudah dilakukan oleh pemerintah, untuk menjaga keberadaan rumah tersebut sesuai dengan prinsip pemugaran, yaitu mempertahankan keaslian bentuk, tata ruang, teknik pengerjaan, dan bahan. Secara fisik, keaslian bentuk atau otentisitas rumah adat di Teluk Selong masih terjaga, tetapi lingkungan dalam zona inti dan zona penyangga telah berubah. Jalan setapak menuju rumah adat yang dulu berupa titian kayu, kini berubah menjadi titian beton cor. Lingkungan rumah adat yang dulu berupa lahan rawa kini sebagian telah berubah menjadi areal parkir dengan permukaan konblok (paving block).
Pengelolan sumber daya budaya yang tidak berpegang pada kaidah pelestarian seperti yang tercantun dalam UU RI No. 11 Tahun 2010 tentang Cagar Budaya, akan berakibat pada berkurangnya nilai keaslian cagar budaya tersebut, serta dampak fisik dan sosial budaya yang dapat merugikan masyarakat sekitar dan mengancam keberadaan rumah adat. Pengelolaan yang baik dan benar seharusnya mendukung pelestarian sumber daya budaya supaya tidak kehilangan nilai keaslian dan sejarahnya.

Pelestarian lingkungan situs diwujudkan dalam bentuk pemintakatan lahan atau zonasi. Pemintakatan pada kawasan situs cagar budaya dikenal 3 zona, yaitu zona inti (core zone) yang merupakan area situs tidak boleh ada tambahan bangunan selain situs yang merupakan inti konservasi; zona penyangga (buffer zone) merupakan area penyangga situs yang dimanifestasikan dalam bentuk penataan lansekap taman dan tanaman (green belt) sebagai objek alternatif sebelum atau sesudah mengunjungi objek utama; serta zona terluar yaitu zona pengembang (development zone) yang di dalamnya dapat dibangun fasilitas pengunjung dan pelayanan publik, seperti area parkir dan cafe (Nuryanti 2005: 20).

Ada kesenjangan antara yang seharusnya dengan yang telah terjadi dalam pengelolaan rumah adat di Teluk Selong Ulu. Berdasarkan paparan di atas, masalah dirumuskan sebagai berikut:

1. Bagaimana dampak dari pengelolaan dan pengembangan kawasan rumah adat Banjar di Teluk Selong Ulu terhadap lingkungan sekitar?

2. Bagaimana model strategi pengelolaan kawasan rumah adat di Teluk Selong yang ideal berdasarkan pendekatan prinsip pelestarian sumber daya arkeologi dan kearifan lokal?

Tujuan penelitian adalah untuk mengidentifikasi dampak yang ditimbulkan dari kegiatan pengelolaan dan pengembangan kawasan rumah adat Banjar terhadap lingkungan sekitar, serta membuat model strategi pengelolaan kawasan rumah adat di Teluk Selong berdasarkan pendekatan prinsip pelestarian sumber daya arkeologi dan kearifan lokal. 
Tujuan ini didasari oleh permikiran bahwa rumah adat Banjar di Teluk Selong mempunyai potensi yang sangat tinggi untuk dilestarikan sebagai cagar budaya dan dikembangkan menjadi objek pariwisata. Berbagai upaya pengelolaan untuk mengoptimalkan eksistensi rumah adat dilakukan oleh pemangku kepentingan yang mengapresiasi melalui kunjungannya ke rumah adat. Dalam proses pengelolaan tersebut, ada beberapa hal yang tidak sesuai dengan prinsip pelestarian, misalnya pembangunan area parkir dengan mengurug lahan rawa menjadi konblok. Hasil dari Workshop forProtection of Cultural Heritage in Martapura pada tahun 2012 oleh Cultural Heritage Protectiopn Cooperation Office, Asia Pacific Cultural Centre for Unesco (APCCU), merekomendasikan supaya konblok tersebut dibongkar dan diganti dengan papan kayu, karena beton tidak sesuai dengan bangunan tradisional rumah panggung. Pada sisi lain, rumah adat Banjar dan kawasannya mempunyai peluang dan harapan yang dapat dimanfaatkan untuk membuat strategi pengelolaan yang ideal sehingga rumah adat Banjar sebagai sumber daya budaya dapat dimanfaatkan secara optimal sebagai simbol jatidiri daerah dan aset wisata budaya.

Strategi pengelolaan sumber daya dibuat untuk mempertahankan fungsi dan keberadaan sumber daya secara maksimal. Strategi merupakan cara yang terstruktur untuk melaksanakan suatu kegiatan. Pengelolaan sumber daya budaya (cultural resource management) meliputi 3 aspek, yaitu: identifikasi dan evaluasi sumber daya budaya (yang merupakan bentuk penelitian), penanganan sumber daya yang merupakan bentuk pelestarian, dan manajemen sumber daya jangka panjang yang merupakan bentuk dari pengembangan. Identifikasi dan evaluasi perlu untuk menentukan bagian-bagian yang harus diperlakukan, terutama identifikasi lokasi atau keletakannya, dan mengukur potensi situs berkaitan dengan sejarah manusia yang tinggal di tempat tersebut. Aspek penanganan sumber daya untuk menentukan jenis penanganan yang tepat sesuai dengan identifikasi sumber daya, bagian yang akan rusak sehingga perlu preservasi, dan tindakan-tindakan lain untuk stabilitasi sumber daya dan mencegah kemungkinan gangguan yang akan terjadi pada masa yang akan datang seperti erosi, longsor, dan naiknya permukaan air tanah. Aspek ketiga yaitu manajemen jangka panjang diperlukan untuk pengelolaan dalam waktu yang relatif lama dan berkesinambungan, meliputi identifikasi dan evaluasi, penanganan in situ, dan pemeliharaan (Mundardjito 2008: 7-22).

\section{METODE}

Jenis metode yang digunakan dalam penelitian ini adalah kualitatif dengan penalaran induktif yang bertujuan menjelaskan makna dibalik fakta. Metode ini berkaitan dengan permasalahan penelitian yang berfokus pada dampak pengelolaan yang akan menjadi dasar untuk menyusun model strategi pengelolaan. Dalam metode ini, teori bukan hal yang utama, tetapi konsep dan kategori lebih penting dari pada kejadian. Penelitian tidak bermaksud untuk menggambarkan karakter populasi tertentu, tetapi pada representasi fenomena sosial (Brannen 1997: 13 dan Bungin 2003: 53).

Sumber data dalam penelitian kualitatif terdiri atas informan, peristiwa, lokasi, dan dokumen atau arsip. Informan sebagai pemilik informasi, juga sebagai aktor yang menentukan berhasil tidaknya sebuah penelitian berdasarkan informasi yang diberikan (Moleong 1989: 122-127; Suprayogo dan Tobroni 2003: 162-165). Dalam penelitian ini, informasi digali dengan pengamatan secara cermat mengenai kondisi rumah adat dan lingkungan sosial serta biofisiknya.

Instrumen penelitian merupakan alat pengumpul data, yang dalam penelitian ini adalah peneliti. Peneliti menjadi segalanya dalam proses penelitian, yaitu menjadi perencana, pelaksana pengumpul data, analisis penafsir data, dan penulis hasil penelitian (Moleong 1989: 132). Pengumpulan data dalam penelitian ini dilaksanakan dalam waktu sekitar empat bulan, tahap demi tahap dan sifatnya berkembang. Antara pengumpulan data dan analisis data dilaksanakan secara simultan. Pengumpulan data dibagi dalam 3 teknik, yaitu observasi, wawancara, dan dokumentasi. Pada penelitian ini juga dilakukan participatory rural appraisal (PRA), yaitu merupakan teknik menggali informasi yang melibatkan masyarakat sebagai subjek untuk merumuskan suatu rencana kerja dalam wilayah 
teritorial masyarakat tersebut berdasar analisis mereka terhadap isu masalah (Saptono 2013: 3839).

Analisis meliputi kegiatan penelaahan, pengelompokan, sistematisasi, penafsiran, dan verifikasi data agar sebuah fenomena memiliki nilai sosial, akademis atau ilmiah (Suprayogo dan Tobroni 2003: 191). Pengolahan data dilakukan sejak pengumpulan data, yaitu dengan melakukan reduksi data, dilanjutkan dengan penyajian data, dan verifikasi yang dilanjutkan dengan menarik kesimpulan (Suprayogo dan Tobroni 2003: 191-197). Analisis dalam penelitian ini akan menggunakan sistem analisis SWOT (Strength, Weakness, Opportunities, Threats). Analisis SWOT merupakan metode perencanaan strategis berdasarkan logika untuk mengevaluasi berbagai faktor secara sistematis dengan memaksimalkan kekuatan dan peluang tetapi secara bersamaan dapat meminimalkan kelemahan dan ancaman (Rangkuti 2013: 19-20).

\section{HASIL DAN PEMBAHASAN}

\section{Potensi Kawasan Rumah Adat Banjar di Teluk Selong Ulu}

Mengacu pada Undang-Undang Nomor 11 Tahun 2010 tentang Cagar Budaya, kawasan merupakan kesatuan ruang geografis yang mempunyai dua situs cagar budaya atau lebih yang letaknya berdekatan atau memperlihatkan ciri ruang yang khas. Dengan demikian, kawasan yang dimaksud dalam tulisan ini meliputi lingkungan fisik, sosial, serta objek cagar budaya.

Masyarakat Teluk Selong dari zaman dahulu terkenal sebagai perajin intan, batu akik, dan berbagai jenis batu mulia lainnya. Beberapa di antaranya menjadi pedagang yang memperjualbelikan perhiasan tersebut hingga keluar Pulau Kalimantan, antara lain ke Jawa, Singapura, dan Srilanka (Ceylon). Kata Teluk Selong berasal dari kata "Ceylon". Ada juga yang mengatakan bahwa selong berasal dari bahasa Banjar yang artinya batu yang potongannya tidak rata (pers.com dengan lbu Naziroh, 50 tahun, di Teluk Selong pada 11 Mei 2014).

Ketika industri batu mulia meredup, perajin di Teluk Selong beralih kerajinan ke biji pulkaha (tahun 2007 hingga pertengahan 2014), tetapi ketika kini batu akik mulai terkenal maka perajin pun beralih ke pengasahan batu akik. Biji pulkaha didatangkan dari Timur Tengah dalam bentuk biji yang bentuknya bulat panjang seperti mainan gasing. Biji tersebut dipotong-potong dengan menggunakan mesin dan gerenda menjadi biji untuk dirangkai menjadi biji tasbih, gelang, dan kalung. Batu akik dengan bahan dasar batu lokal, terutama jenis batu red borneo yang kini (tahun 2015) menjadi trade mark batu akik Kalimantan. Batu tersebut ditambang di daerah Riam Kanan sekitar Pegunungan Meratus, dijual dalam bentuk bongkahan yang kemudian dibuang kulit batunya, dipotong-potong, dibentuk dan diasah sesuai

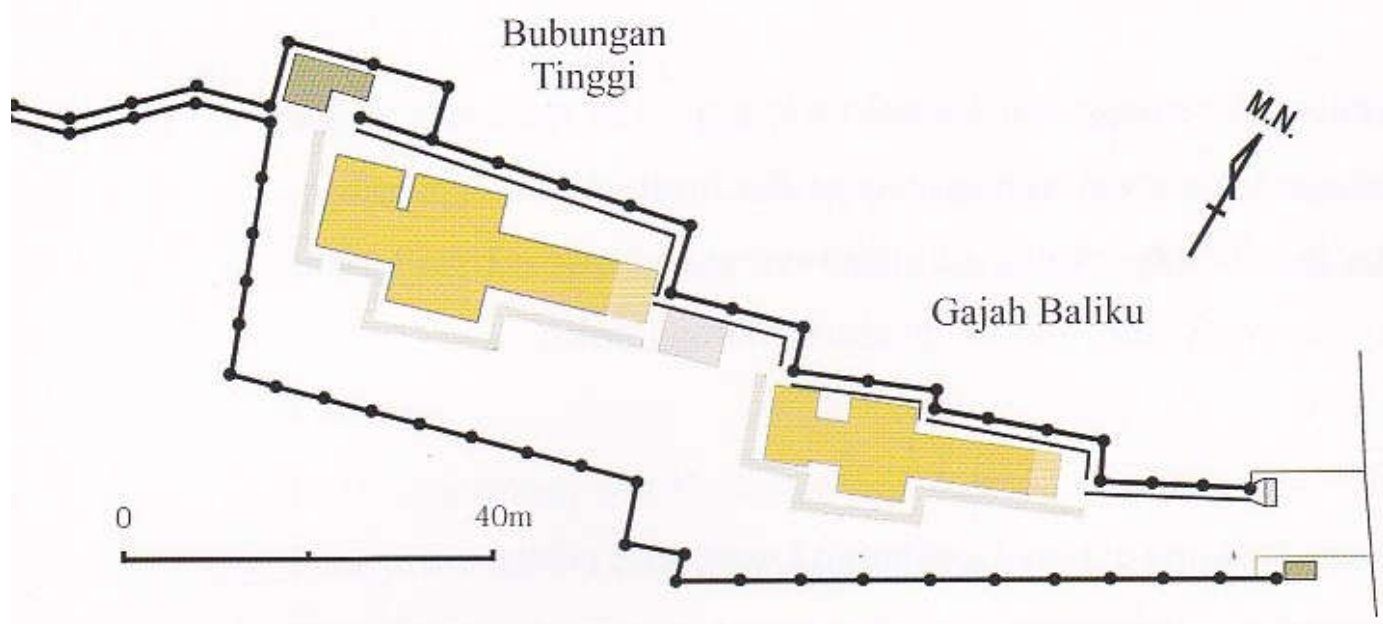

Sumber: APCCU, 2013

Gambar 1. Peta situasi kawasan rumah adat Banjar di Teluk Selong 
bentuk yang diinginkan. Pekerjaan tersebut dilakukan oleh laki-laki. Perempuan di Teluk Selong mengerjakan kerajinan sulaman dan air guci, yaitu merangkai perhiasan manik-manik dengan teknik jahit dan tempel pada kain.

Dua buah rumah adat Banjar berdiri megah dan tampak masih asli, yaitu rumah adat tipe Bubungan Tinggi dan rumah adat tipe Gajah Baliku. Kedua rumah tersebut terletak berdekatan dengan posisi muka belakang, yaitu rumah Gajah Baliku posisi di depan menghadap jalan desa dan Sungai Martapura, sedangkan rumah Bubungan Tinggi terletak di belakang agak ke samping kiri.

Rumah Bubungan Tinggi di Teluk Selong dibangun pada tahun 1867 oleh saudagar batu permata bernama H.M. Arif dan Hj. Patimah, dan kini ditempati oleh Fauziah (57 tahun). Rumah ini mempunyai beberapa ruangan dengan nama dan ukurannya berbeda, yang apabila dijumlahkan luasnya sekitar $374,21 \mathrm{~m}^{2}$, dengan tinggi 11,5 meter ditambah tinggi tonggak 2,25 meter sehingga tinggi keseluruhan dari permukaan tanah adalah 13,75 meter.

Organisasi ruang dalam rumah adat Banjar terdiri atas 4 bagian, bagian pertama paling depan disebut palataran depan atau surambi, berupa teras terbuka dan setengah terbuka dengan dinding kayu setinggi 1 meter. Bagian kedua, ruangan paling depan merupakan ruang tamu, bagian ketiga merupakan ruangan baanjung yang paling luas digunakan sebagai ruang keluarga atau ruang tinggal, sedangkan bagian keempat merupakan ruang belakang (memasak/ menyiapkan makanan) yang lantainya lebih rendah dari ruang lainnya. Nama ruang, fungsi, dan ukuran rumah Bubungan Tinggi secara detail dalam Muchamad dan Mentayani (2007: 15-21) dan APCCU (2013: 19-20) dapat dilihat pada tabel 1 dan 2 (lampiran).

Bangunan rumah Bubungan Tinggi jika dilihat dari samping tampak tujuh jenjang mulai dari halaman depan (palatar) hingga dapur (padapuran). Jika panampik tangah dan panampik bawah dihilangkan, maka akan tampak lima jenjang, sehingga jumlahnya tetap ganjil. Rumah Bubungan Tinggi mempunyai aneka hiasan berbentuk ukiran yang bervariasi. Ukiran bermotif stiliasi flora atau suluran dan kaligrafi terdapat pada pintu masuk dan dinding pembatas dalam (tawing halat). Ukiran pada pagar teras depan (palataran dalam) berupa motif tatah kandang rasi.

Rumah Gajah Baliku di Teluk Selong dibangun oleh pasangan pedagang permata bernama H. Jalil dan $\mathrm{Hj}$. Esah sekitar tahun 1880. Rumah Gajah Baliku tersebut kini dihuni oleh Najib, cucu keponakan Hj. Esah. Rumah Gajah Baliku mempunyai atap yang membubung ke depan berbentuk pelana, tetapi pada ujung depannya berbentuk piramida. Teras depan didukung oleh empat buah tiang yang bertumpu di atas tanah. Konstruksi bubungan depan ini menyerupai kepala gajah sehingga dinamakan gajah baliku.

Rumah Gajah Baliku mempunyai dua buah tangga, yaitu tangga depan (tangga hadapan) dan tangga belakang yang posisinya di tengahtengah. Tangga depan terletak di palatar, di atas tangga depan terdapat lawang hadapan (pintu depan), sedangkan tangga belakang terletak di dapur. Nama dan ukuran ruang rumah adat Gajah Baliku menurut Seman dan Irhamna (2006: 21-26) dan APCCU (2013: 15-20) dapat dilihat pada Tabel 2 (lampiran).

Kedua rumah adat, yaitu Bubungan Tinggi dan Gajah Baliku, telah ditetapkan oleh pemerintah sebagai bangunan Cagar Budaya. Syarat utama sebagai cagar budaya adalah usia minimal 50 tahun, belum pernah berubah baik dari segi bentuk dan ukuran, serta mempunyai nilai penting bagi ilmu pengetahuan dan sejarah. Kedua rumah tersebut telah dipugar berkali-kali karena kondisinya yang sudah sangat tua, seperti penggantian atap, dinding, dan lantai sudah pernah dilakukan (Tim Penelitian 2012: 36-37). Rumah Bubungan Tinggi pernah dipugar tiga kali, yaitu pada tahun 1989, 2005, dan 2010-2011.

Buku Anatomi Rumah Bubungan Tinggi (2007: 11-12) menyebutkan bahwa pada masa pendudukan Jepang (1942-1945) rumah Bubungan Tinggi pernah digunakan sebagai markas para pejuang melawan Jepang. Penuturan informan, Ibu Naziroh (60 tahun), cicit pendiri rumah Bubungan Tinggi, pada waktu kecil ibunya pernah bercerita bahwa pada masa Jepang ibunya pernah mengungsi ke rumah Bubungan Tinggi karena rumah tinggalnya yang 
ada di depan rumah Bubungan Tinggi dikuasai oleh tentara Jepang. Tidak ada informasi yang pasti tentang kontribusi rumah ini pada sejarah perjuangan. Namun demikian, kedua rumah tersebut mewakili gaya arsitektur lokal yang bernilai penting bagi sejarah dan proses perubahan budaya lokal. Nilai sejarah berkaitan dengan perkembangan arsitektur lokal dan pergeseran kepemilikan dari raja menjadi milik rakyat biasa, yang diawali dengan runtuhnya Kerajaan Banjar (Saleh 1980/1981: 41-42).

Kedua rumah adat tersebut secara teknis memiliki potensi kerusakan yang menjadi ancaman bagi keberadaanya. Dari hasil penelitian Workshop APCCU 2013, diketahui bahwa pada kedua rumah tersebut terdapat beberapa bagian rumah yang rusak karena kondisi cuaca maupun karena jamur dan binatang. Bagian atap banyak terdapat kotoran kelelawar yang dapat mengakibatkan kerusakan atap, dinding luar banyak terdapat jamur, pada beberapa tiang bawah rumah dan dinding luar ditumbuhi jamur dan dimakan rayap. Bagian atap bocor sehingga air hujan menetes ke dinding dan lantai, apabila dibiarkan akan membuat dinding kayu rusak. Beberapa tiang bawah (tonggak) yang telah rusak disarankan supaya diganti dengan tiang yang baru, dengan pemberian bantalan pondasi tiang. Semua peserta workshop juga menyarankan untuk mengganti pasangan blok beton diganti dengan papan kayu karena beton tidak cocok dengan harmoni bangunan tradisional. Hal tersebut dilakukan sebagai upaya untuk mengembalikan bentuk dan lingkungan (APCCU 2013: 19-20). Upaya preservasi perlu dilakukan secara rutin sebelum jamur dan rayap tumbuh subur, karena bangunan kayu keras (ulin) tahan terhadap reaksi iklim tetapi rentan terhadap aksi biologis seperti jamur dan rayap (Lippsmeier 1980: 56-57).

Hubungan yang intens antara manusia dan lingkungannya dalam waktu yang lama telah berhasil membentuk kesatuan ruang budaya (Rossle dan Cleere 2001: 17). Hal tersebut tampak pada bentuk fisik bangunan, yaitu dari desain ruangan yang luas menunjukkan bahwa ada nilai interaksi sosial yang lahir lewat hubungan kekeluargaan, karena rumah adat dihuni oleh keluarga besar. Bentuk tiang (tonggak di bawah latai) yang tinggi, menunjukkan adanya nilai adaptasi lingkungan, karena Teluk Selong merupakan daerah rawa pasang surut yang sering banjir karena luapan air Sungai Martapura.

Bentuk arsitektur atap yang tinggi dan jendela yang lebar merupakan perwujudan dari nilai strategi adaptasi daerah rawa tropis, yaitu supaya sirkulasi udara dan cahaya maksimal, sehingga suasana di dalam rumah terasa nyaman. Usia rumah adat yang sudah lebih dari 130 tahun, tetapi terjaga keaslian bahan dan fasat depannya, kedua rumah tersebut menunjukkan adanya nilai kekuatan konstruksi dan konsistenitas ahli waris untuk menjaga warisan budaya. Nilai religius tampak dengan hadirnya ukiran pada tawing halat (dinding pembatas) berupa kaligrafi berbunyi bacaan tahlil "Laa illa ha illallaah" yang artinya Tiada Tuhan selain Allah (mengesakan Allah) dan stiliran flora bermakna kesejahteraan. Tidak adanya motif hewan dan manusia menunjukkan bahwa nilai agama Islam dijunjung tinggi, karena dalam ajaran agama Islam lukisan hewan dan manusia tidak diperkenankan (Hartatik 2014: 70).

\section{Dampak Pengelolaan dan Pengembangan Kawasan Rumah Adat}

Rawa merupakan lahan yang tergenang secara periodik atau terus menerus secara alami dalam waktu lama akibat drainase alamiah. Hilangnya sebagian lahan rawa yang diurug menjadi lahan beton seluas sekitar $1.425 \mathrm{~m}^{2}$ berdampak pada kondisi hidrologi di sekitar rumah adat. Sebelum adanya halaman beton, lahan di sekitar rumah adat merupakan lahan basah yang selalu tergenang air dan akan surut jika musim kemarau panjang tiba. Rawa terbuka tersebut merupakan daerah resapan air, sehingga ketika hujan turun dengan deras lebih dari 4 jam, debit air rawa akan meningkat, air Sungai Martapura meluap ke kampung, tetapi tidak sampai ke depan pintu rumah. Debit air selalu berada pada posisi di bawah lantai rumah, karena tinggi tonggak atau tiang di bawah rumah sekitar 2 meter.

Masyarakat sekitar rumah adat, secara langsung tidak merasakan dampak biofisik maupun dampak hidrologi atas keberadaan alih fungsi lahan tersebut, seperti lbu Naziroh, yang rumahnya berjarak sekitar 50 meter dari halaman 
rumah adat. Jika musim hujan, air biasa menggenangi halaman depan tetapi tidak masuk ke rumah panggung, karena sebagian besar air hujan dan luapan Sungai Martapura langsung menuju ke rawa-rawa yang masih luas di belakang rumah adat.

Selain dampak perubahan biologis dan fisik berskala kecil yang tidak sampai dirasakan oleh masyarakat, sampah merupakan masalah lingkungan yang ditimbulkan oleh kehadiran pengunjung rumah adat. Banyak pengunjung yang membuang sampah (terutama sampah bekas minuman kemasan) di kolong rumah. Pengunjung melemparkan sampah tersebut begitu saja ke kolong atau halaman rumah adat. Kehadiran sampah yang mengumpul di depan dan kolong rumah adat tidak sedap di pandang mata. Meskipun belum dirasakan mengganggu lingkungan, dalam jangka panjang sampah plastik dapat merusak air tanah karena cemaran kandungan kimianya.

Masyarakat tidak mempermasalahkan berkurangnya lahan resapan air, karena lahan rawa di sekitarnya masih luas untuk tumbuhnya dan hewan rawa serta tampungan air hujan. Masyarakat juga tidak mempermasalahkan kebisingan dan asap karena lalu lalang kendaraan pengunjung yang melintas. Keberadaan rumah adat dengan pengembangan kawasannya tidak (belum) menimbulkan dampak biologi dan fisik yang merugikan masyarakat sekitar. Terganggunya ekosistem rawa yang menyebabkan perubahan hubungan timbal balik antara makhluk hidup dan lingkungannya, belum berlaku dalam kasus reklamasi lahan di kawasan rumah adat Teluk Selong Ulu. Meskipun demikian, antisipasi berupa pencegahan reklamasi lahan perlu dilakukan supaya dalam jangka panjang kerusakan lingkungan tidak terjadi.

Menurut masyarakat sekitar, setelah dibuat halaman beton, titian beton, dan taman, keberadaan rumah adat "tidak bagus lagi". Istilah tersebut digunakan untuk menyatakan bahwa rumah adat, terutama di halamannya dimanfaatkan untuk hal-hal yang negatif oleh sebagian pengunjung dari kampung lain. Bahkan dicurigai beberapa anak muda yang memanfaatkan halaman rumah tersebut untuk transaksi obat terlarang, dan "ngelem" (menghirup lem yang bisa memabukkan, biasanya dilakukan oleh anak-anak di bawah umur yang belum mampu membeli narkoba). Di tempat tersebut juga sering terjadi perkelahian. Masyarakat khawatir jika hal tersebut dibiarkan berkepanjangan akan menimbulkan pengaruh yang tidak baik bagi penduduk Teluk Selong, terutama bagi anak-anak mudanya.

Permasalahan keamanan sosial di kawasan rumah adat, Abdul Said yang tinggal sekitar 100 meter dari rumah adat, menyarankan supaya dibuat pagar di jalan belakang yang bisa dikunci pada malam hari, karena kebanyakan pengunjung "liar" lewat jalan belakang yang sepi dan tidak terlihat penduduk. Jalan depan rumah tidak diberi pintu berkunci tidak apa-apa, karena orang yang keluar masuk ke kawasan rumah adat dapat diawasi oleh masyarakat sekitar.

Dampak pengembangan rumah adat sebagai objek wisata yang secara langsung dirasakan oleh juru pelihara (jupel) adalah berkurangnya rasa aman. Banyaknya pengunjung yang datang ke rumah adat menyebabkan dia harus ekstra hati-hati karena sering kehilangan harta benda, sehingga dia sering menutup dan mengunci pintu dari dalam rumah. Padahal sebagai cagar budaya yang dikembangkan sebagai objek wisata, rumah tersebut terbuka untukumum. Menurut Fauziah, juru pelihara rumah Bubungan Tinggi, alasan menutup pintu karena ia merasa tidak aman. Suatu saat ketika pintu dibuka dan dia beraktivitas di dapur, ternyata kamera dan sejumlah uang yang disimpan di almari di ruang tengah hilang. Demikian juga uang hasil jualan souvenir dan minuman ringan yang disimpan di ruang depan dekat etalase. Beberapa minuman kemasan dalam almari pendingin juga sering hilang.

Faktor keamanan menjadi masalah baru setelah banyaknya pengunjung yang mendatangi rumah adat. Masalah ini tidak akan berkepanjangan jika ada solusi yang didukung oleh stakeholder, terutama dari pihak Pemerintah Kabupaten Banjar (Dinas Kebudayaan dan Pariwisata) dan Balai Pelestari Cagar Budaya (BPCB). Alternatif atau solusi pertama, adalah menambah tenaga pengamanan atau petugas jaga (jupel), dan membuat pintu pengaman di jalan masuk belakang; alternatif kedua adalah dengan 
mengosongkan rumah adat (tanpa isi atau barangbarang berharga), dengan konsekuensi ahli waris yang pasti akan merasa keberatan jika tanpa kompensasi.

Pada hakikatnya, arti sebuah warisan budaya tergantung pada pemangku kepentingan, yaitu penanganan pelestarian dan pemanfaatannya (Raharjo dan Muluk 2011: 149). Dampak sosial yang timbul berupa kekhawatiran masyarakat sekitar dan keresahan juru pelihara karena perilaku beberapa pengunjung yang cenderung negatif, seperti mencuri, berkelahi, berpacaran, dan bahkan transaksi narkoba. Konflik kepentingan juga muncul setelah adanya pengembanangan kawasan berupa reklamasi lahan, yaitu konflik internal antara perangkat desa dengan ahli waris, ahli waris dengan juru pelihara, dan juru pelihara dengan Dinas Kebudayaan dan Pariwisata Kabupaten Banjar (Hartatik 2014: 8688)

\section{Analis Pengelolaan}

Pelestarian rumah adat Banjar dengan menjadikannya sebagai kawasan pariwisata ibarat pisau bermata dua. Di satu sisi, pariwisata dapat mendongkrak eksistensi rumah adat, tetapi pada sisi yang lain pengembangan kawasan pariwisata yang tidak terarah akan berdampak pada keberadaan rumah adat dan penurunan kualitas lingkungan. Pengelolaan yang benar dan terpadu antarstakeholder diperlukan dalam upaya pelestarian dan pemanfaatan rumah adat sebagai objek wisata budaya. Pengembangan kawasan cagar budaya harusnya didasarkan pada konsep zonasi tata ruang bangunan bersejarah (Mundardjito 2008: 7-22). Sayang sekali, zonasi di kawasan rumah adat Banjar belum ada, rencananya baru akan dibuat oleh BPCB Samarinda pada tahun 2015 (Wawancara dengan Kasubbag TU BPCB Samarinda, Juli 2014).

Model strategi pengelolaan kawasan rumah adat Teluk Selong dibuat berdasar konsep pelestarian sumber daya arkeologi dan kearifan lokal. Berbagai faktor internal dan eksternal yang berpengaruh dianalisis dengan menggunakan analisis SWOT. Analisis SWOT merupakan metode perencanaan strategis berdasarkan logika untuk mengevaluasi berbagai faktor secara sistematis dengan memaksimalkan kekuatan (Strength) dan peluang (Opportunities), tetapi secara bersamaan dapat meminimalkan kelemahan (Weakness) dan ancaman (Threats) yang terdapat pada kawasan rumah adat Banjar di Teluk Selong.

Pendekatan kualitatif dengan menggunakan matriks SWOT mendasarkan pada isu-isu strategis yang timbul sebagai hasil pertemuan antara faktor-faktor internal dan eksternal dalam pengelolaan kawasan rumah adat Banjar. Sebagai sumber daya budaya, rumah adat Banjar mempunyai kekuatan atau kelebihan yang harus dimanfaatkan untuk mengatasi kelemahan dan ancaman. Berbagai hal yang mempengaruhi keempat faktor dan dianalisis, kemudian diterapkan dalam gambar matriks SWOT. Melalui matriks SWOT akan diperoleh pemahaman guna meningkatkan potensi untuk meraih peluang, serta mengurangi kelemahan dan ancaman. Berdasarkan pemahanan tersebut kemudian diselaraskan dengan program-program yang telah ada sesuai harapan stakeholder.

\section{Kekuatan (Strength)}

Kekuatan utama kawasan rumah adat Banjar terletak pada keberadaan dua buah rumah adat Banjar dengan arsitektur tradisional yang unik dan indah (estetis). Keunikan dan keindahan tersebut merupakan magnet yang menarik perhatian dan minat pengunjung untuk datang. Selain masyarakat sekitar, pengunjung datang dari berbagai kelompok masyarakat seperti kelompok fotografer, perajin sasirangan, kelompok modelling, dan stasiun televisi yang datang untuk mengadakan kegiatan seperti acara demo memasak, demo tarian, buka bersama, atau sekedar berfoto dengan objek atau back ground rumah adat.

Selain itu, rumah adat Banjar tersebut juga mempunyai arsitektur yang adaptif (sesuai harmoni lingkungan) sebagai perwujudan nilai kearifan lokal pembuatnya. Nilai kearifan diharapkan dapat ditransfer sebagai pemahaman kepada masyarakat tentang arti pentingnya menjaga harmoni lingkungan, salah satu caranya dengan membangun rumah panggung, tanpa mengurug lahan yang dapat berakibat fatal pada penurunan kualitas lingkungan. 
Aspek usia bangunan yang lebih dari 130 tahun, keaslian bentuk, bahan, desain, asosiasi, dan lokasi merupakan faktor otentisitas data arkeologi sebagai wujud budaya fisik yang harus tetap dipertahankan. Jika ada kerusakan, sesuai dengan Undang Undang Cagar Budaya, maka perbaikan dilakukan tetapi sesuai dengan bentuk, bahan, dan desain aslinya.

Rumah adat dengan tata ruang yang fungsional sesuai kondisi masyarakat Banjar dan sarat dengan pesan religius merupakan salah satu bentuk warisan budaya yang layak dibanggakan dan dilestarikan. Dari wawancara dengan pengunjung dan masyarakat sekitar, hampir semua menyatakan kebanggaannya memiliki rumah adat sebagai bagian dari budaya Banjar. Kebanggaan tersebut merupakan salah satu modal untuk melibatkan masyarakat dalam pelestarian rumah adat sebagai media pembelajaran tentang kearifan lokal bagi generasi mendatang.

Kawasan rumah adat Banjar di Desa Teluk Selong Ulu terletak di tepi jalan raya arah Martapura - Dalam Pagar, sekitar 4 km dari kota Martapura. Posisi tersebut sangat mudah dijangkau dengan menggunakan kendaraan pribadi atau umum, sepeda, bahkan dengan perahu menyusuri Sungai Martapura yang terletak sekitar 100 meter di depan rumah adat. Banyaknya kunjungan ke rumah adat Banjar, tidak lepas dari peran biro perjalanan dan lembaga atau instansi budaya yang membawa pengunjung ke rumah adat, baik wisatawan domestik, turis, maupun rombongan siswa dan peserta kegiatan tertentu. Melalui kunjungan tersebut, maka pesanpesan tentang pelestarian dan nilai kearifan lokal rumah adat dapat disampaikan, baik secara visual dengan melihat langsung maupun verbal melalui penjelasan juru pelihara dan tour guide.

Kondisi lingkungan Teluk Selong Ulu merupakan lingkungan kampung khas Banjar dengan deretan rumah panggung di tepi jalan dan sungai, merupakan nilai lebih yang perlu dimunculkan. Mata pencaharian sebagian besar penduduk sebagai perajin perhiasan dari bahan batu, kayu, dan air guci (manik-manik) merupakan daya tarik tersendiri yang unik. Hamparan tanaman rawa merupakan pemandangan yang eksotis untuk dinikmati dalam perjalanan, juga indah untuk dinikmati ketika berada di halaman dan di depan jendela dari dalam rumah adat (Hartatik 2014: 102)

\section{Kelemahan (Weakness)}

Pengembangan lingkungan rumah adat Banjar menjadi kawasan wisata dengan dana pemerintah pusat melalui Kimpraswil Provinsi pada tahun 2010-2011 dengan membuat halaman beton dan titian beton, terbukti telah merusak sistem zonasi kawasan cagar budaya, sekaligus membuat tidak harmoninya lingkungan rumah adat. Alih fungsi lahan yang semula rawa menjadi lahan beton berukuran sekitar $1.425 \mathrm{~m}^{2}$, berdampak pada penurunan kualitas lingkungan, meskipun dampak itu tidak dirasakan secara langsung oleh masyarakat sekitar. Dampak yang saat ini terasa adalah berkurangnya ekosistem rawa, vegetasi, dan binatang rawa, serta dampak hidrologi berupa debit air di bawah rumah yang cepat naik pada musim hujan dan cepat surut jika beberapa hari tidak hujan karena berkurangnya daerah resapan air.

Faktor usia menjadi salah satu hal yang harus diperhitungkan dalam perawatan rumah kayu, karena seiring dengan usia tua yang rentan terhadap pertumbuhan jamur dan rayap yang merusak kayu. Kondisi tersebut menyebabkan beberapa bagian atap dan dinding rapuh, serta tonggak di bawah lantai telah mengalami kemiringan.

Sistem pengelolaan yang multi stakeholder, bila bersinergi tentu akan membuahkan hasil yang optimal, tetapi karena tidak terkoordinir dengan baik justru menciptakan beberapa kesalahan dalam pengelolaan. Masing-masing merasa berkepentingan sesuai dengan bidang kerjanya. Hal tersebut diperparah karena tidak semua pejabat pengambil keputusan memahami arti penting warisan budaya dan pengelolaan kawasan cagar budaya yang berada dalam zonasi yang dilindungi undang-undang. Banyak yang beranggapan bahwa yang harus dilestarikan hanyalah rumahnya, sementara halaman rumah bebas dibuat apa saja. Ketidakpahaman tentang zonasi kawasan cagar budaya, berakibat fatal pada keputusan dibuatnya halaman beton dengan mengurug lahan rawa, karena rawa yang penuh belukar dan kumuh dinggap tidak bermanfaat. 
Beberapa pengunjung yang datang ke rumah adat, banyak yang tidak memahami tentang nama, bentuk, fungsi, sejarah, dan nilai yang terkandung di dalam rumah adat. Biasanya pengunjung hanya melihat-lihat sekilas kemudian memotret, baik memotret objek maupun foto selfi. Mereka enggan bertanya kepada juru pelihara, mungkin dikira harus membayar, malu atau takut bertanya. Hal tersebut antara lain karena belum ada informasi yang lengkap secara tertulis tentang keberadaan rumah adat, misalnya leaflet atau brosur yang bisa dibaca dan dibawa pulang oleh pengunjung.

Status kepemilikan rumah adat Banjar di Teluk Selong masih dimiliki secara perorangan oleh masyarakat. Kondisi ini sering menimbulkan pro kontra di antara masyarakat, pengelola, dan pejabat kebudayaan setempat. Di dalam Surat Pernyataan pasca pemugaran yang ditanda tangani oleh ahli waris dan diketahui oleh Kepala Desa Teluk Selong dan Camat Martapura pada 29 Juli 1989, menyatakan bahwa setelah dipugar oleh pemerintah, ahli waris tidak keberatan jika rumah adat tersebut terbuka untuk umum, siapa pun bisa datang mengunjungi. Dalam praktiknya, karena faktor keamanan sering kehilangan, maka rumah Bubungan Tinggi sering dikunci dari dalam oleh penghuninya. Demikian juga rumah adat Gajah Baliku, oleh kerabat yang tinggal di dalamnya dan sekaligus menjadi juru pelihara, rumah tersebut sering ditutup. Alasan menutup pintu karena sekarang ini Pemda Banjar tidak mengeluarkan dana untuk honor juru pelihara, selain honor dari pemerintah pusat lewat BPCB Samarinda (Hartatik 2014: 92-93)

\section{Peluang (Opportunities)}

Hampir semua daerah berusaha menggali potensi masing-masing untuk dikembangkan sebagai objek wisata. Momentum pengembangan potensi daerah untuk pariwisata dapat diarahkan pada wisata budaya berwawasan lingkungan, sehingga pesan-pesan pelestarian dan nilai penting kawasan rumah adat Banjar dapat disampaikan. Dalam ilmu arkeologi, minimal ada 4 nilai penting, yaitu nilai penting historis, arkeologis, nilai penting kepariwisataan dan nilai penting kebudayaan. Semua nilai penting tersebut ada dan melekat kuat pada kawasan rumah adat Banjar.

Sistem pengelolaan rumah adat di Teluk Selong Ulu yang melibatkan multi stakeholders, seharusnya merupakan peluang besar untuk pengembangan yang optimal. Pendataan keberadaan rumah adat sebagai aset nasional oleh pemerintah pusat, maka selayaknya pemerintah daerah harus berperan serta karena rumah adat merupakan aset daerah. Melalui Direktorat Pelestarian Cagar Budaya dan Permuseuman dengan Unit Pelaksana Teknis yaitu Balai Pelestari Cagar Budaya (BPCB) di Samarinda, Pemerintah Pusat hingga kini mendanai honor juru pelihara, sedangkan Pemerintah Daerah melalui Dinas Kebudayaan dan Pariwisata melakukan pembinaan.

Keberadaan rumah adat ternyata menjadikan kebanggaan tersendiri bagi masyarakat sekitar dan pengunjung. Hal tersebut merupakan motivasi bagi masyarakat untuk turut melestarikannya, meskipun untuk mewujudkan atau membangun rumah adat Banjar pada saat ini mereka menyatakan belum tentu mampu. Setidaknya, nilai penting bagi budaya lokal yang berwawasan lingkungan dapat ditransfer dan dipahami oleh masyarakat.

Adanya Rencana Tata Ruang Wilayah (RTRW) dan Rencana Pembangunan Kawasan Permukiman Prioritas (RPKPP) Kota Martapura, Teluk Selong Ulu masuk dalam Kawasan Permukiman Cagar Budaya (Laporan Draft Akhir RPKPP, Dirjen Cipta Karya Kementrian PU RI Tahun 2013). Penempatan cagar budaya dalam kebijakan tata ruang kota, berpeluang untuk mengembalikan penataan kawasan rumah adat Banjar sesuai dengan zonasi cagar budaya (Hartatik 2014: 95-96)

\section{Ancaman (Threaths)}

Bangunan rumah adat berbahan kayu sangat sensitif terhadap kondisi lingkungan tropis yang cenderung lembab. Dengan perawatan yang baik, jenis kayu keras (ulin) tahan terhadap reaksi iklim dan hujan, karena penguraian sel-sel kayu oleh air, panas, angin, udara, dan cahaya. Akan tetapi, kayu mempunyai kelemahan pada ketahanan terhadap organisme, yaitu tidak tahan 
terhadap rayap dan jamur yang cepat tumbuh di daerah lembab (Lippsmeier 1980: 56-57).

Halaman beton dan titian beton yang menghubungkan jalan belakang rumah hingga halaman depan, jumlah pengunjung rumah adat meningkat tajam dari sebelumnya. Peningkatan jumlah pengunjung disertai dengan dampak sosial yang lebih besar, yaitu meningkatnya tindak pencurian, pengrusakan bangunan, pacaran, mabuk, bahkan ada indikasi transaksi narkoba.

Selain dampak sosial, peningkatan jumlah pengunjung juga disertai dengan dampak fisik berupa limbah makanan dan minuman, terutama dari bahan plastik yang dibuang sembarangan di kolong rumah dan di halaman rumah. Adanya sampah plastik yang menunpuk di kolong rumah membuat pemandanagn tidak nyaman, selain dapat mencemari tanah, bahan plastik sukar diurai oleh zat pengurai.

Kondisi pejabat di tingkat daerah yang cenderung berubah tiap tahun, bahkan bulan, menyebabkan kinerja pemerintah daerah kurang fokus dan kurang efektif. Sering kali terjadi pejabat yang sudah menguasai bidangnya dipindah ke tempat lain, sementara pejabat baru kurang memahami kebijakan dan kinerja di kantor barunya. Hal tersebut juga berakibat pada kurangnya koordinasi antarinstansi sehingga permasalahan yang muncul tidak segera diselesaikan.

Hubungan yang tidak harmonis antara juru pelihara lama dan dan juru pelihara baru (keluarga ahli waris pemilik rumah) merupakan suatu ancaman bagi pengeloaan rumah adat. Kesalahpahaman yang terjadi berkepanjangan di antara ahli waris, juru pelihara, pejabat desa, dan merembet ke pejabat Dinas Kabupaten Banjar bisa berakibat pada tidak optimalnya pengelolaan, sehingga kebersihan dan kelestarian, serta pelayanan terhadap pengunjung bisa terabaikan. Berdasar uraian analisis di atas, dirumuskan matriks analisis SWOT dapat dilihat pada matrik 1.

Matriks 1. Hasil Analisis SWOT (Identifikasi Kekuatan, Kelemahan, Peluang, dan Ancaman)

\begin{tabular}{|c|c|}
\hline Strength (Kekuatan) & Weakness (Kelemahan) \\
\hline $\begin{array}{l}\text { - Arsitektur rumah adat yang unik, estetis, dan adaptif } \\
\text { - Rumah adat ini memiliki nilai historis, } \\
\text { arkelogis,kepariwisataan dan nilai kebudayaan yang } \\
\text { sanat tinggi. } \\
\text { - Lokasi yang mudah dijangkau ( } \pm 4 \text { km dari Kota } \\
\text { Martapura). } \\
\text { - Lingkungan permukiman dan suasana khas Banjar } \\
\text { yang eksotis }\end{array}$ & $\begin{array}{l}\text { - Perubahan setting kawasan berakibat pada } \\
\text { penurunan kualitas lingkungan } \\
\text { - Faktor usia rumah sudah tua sehingga rentan } \\
\text { kerusakan } \\
\text { - Sistem pengelolaan lemah karena benturan } \\
\text { peraturan dan kurangnya pemahaman } \\
\text { pemangku kepentingan } \\
\text { - Status kepemilikan kawasan rumah adat dan } \\
\text { zonasi }\end{array}$ \\
\hline Oppurtunities (Peluang) & Threats (Ancaman) \\
\hline $\begin{array}{l}\text { - Momentum pengembangan potensi daerah } \\
\text { - Pengelola yang multi stakeholders di daerah maupun } \\
\text { - } \text { Kusat } \\
\text { - } \text { budayintahuan dan apresiasi masyarakat akan warisan } \\
\text { - Penempatan cagar budaya dalam kebijakan (RTRW) }\end{array}$ & $\begin{array}{l}\text { - Rumah kayu rentan terhadap pertumbuhan } \\
\text { jamur dan rayap } \\
\text { - Dampak sosial pasca pengembangan kawasan } \\
\text { (keamananan, perkelahian) } \\
\text { - Pencemaran lingkungan akibat limbah } \\
\text { minuman dan makanan pengunjung } \\
\text { - Konflik internal dalam tubuh pengelola dan } \\
\text { instabilitas Pemda }\end{array}$ \\
\hline
\end{tabular}




\section{Model Strategi Pengelolaan}

Strategi Kekuatan - Peluang (Strength Opportunities)

Berdasarkan analisis tersebut dapat disusun model atau strategi pengelolaan kawasam rumah adar Banjar dengan cara mengoptimalkan seluruh kekuatan (S) untuk memanfaatkan peluang (0). Beberapa kekuatan yang ada pada kawasan rumah adat Banjar di Teluk Selong, yaitu adanya tinggalan arkeologi berupa rumah adat dengan arsitektur yang unik, estetis, dan adaptif; nilai otentisitas dan kesejarahan, kepariwisataan rumah adat, lokasi yang mudah dijangkau, lingkungan permukiman dan suasana khas Banjar yang eksotis.

Pembangunan fisik berupa pengembangan kawasan berupa pembuatan halaman dan titian beton dilakukan oleh Dinas PU (Kimpraswil) Provinsi Kalimantan Selatan. Pengelola yang terdiri atas beberapa pemangku kepentingan (multi stakeholders) ini sayangnya tidak ada koordinasi antarlembaga, sehingga terjadi benturan kepentingan antara pengembangan wisata dan pelestarian. Pengelolaan secara terpadu dan terkoordinir dapat menghindari adanya benturan kepentingan, sehingga diperoleh hasil yang optimal. Pengembangan kawasan sebagai objek wisata, idealnya tidak boleh mengabaikan lingkungan (zonasi) bangunan cagar budaya. Dengan pengembangan pariwisata, maka nilai-nilai budaya rumah adat dapat dikenal dan dipahami oleh masyarakat. Dengan adanya rencana Kawasan Permukiman Cagar Budaya Teluk Selong Ulu dalam Rencana Pembangunan Kawasan Permukiman Prioritas, pengeloaan dan pengembangan kawasan rumah adat dapat berjalan sesuai dengan peraturan perundangan, antara lain mengembalikan lingkungan seperti lingkungan asli dan zonasi (Hartatik 2014: 99)

Strategi Kelemahan - Peluang (Weaknesses Opportunities)

Strategi pengelolaan, harus disertai dengan penguatan internal sumber daya dan pengelola yang didapat dengan cara mengatasi kelemahan
(W) untuk meraih peluang (O). Kelemahan yang terdapat di kawasan rumah adat Teluk Selong, antara lain perubahan setting kawasan dengan adanya halaman dan titian beton, sehingga berakibat pada penurunan kualitas lingkungan. Dengan adanya peluang berupa momentum penggalian potensi daerah yang original, setting yang salah yaitu halaman beton perlu diganti atau dikembalikan lagi pada kondisi awal, supaya harmoni rumah adat kembali tercipta. Hal itu sesuai dengan saran dari peserta APCCU dan wacana BPCB Samarinda, dan sebagai gantinya perlu dibuatkan halaman parkir dari papan kayu berbentuk panggung. Hal tersebut perlu dilakukan untuk mengembalikan suasana rumah tradisional yang harmonis dengan lingkungannya.

Kondisi rumah adat berbahan kayu yang sudah berusia lebih dari 130 tahun, menyebabkan rumah tersebut rentan terhadap kerusakan. Bagian yang rusak meliputi bagian atap yang bocor perlu diganti, dinding luar berjamur, sehingga perlu dicat, dan memperbaiki serta mengganti tonggak kayu yang sudah miring. Seluruh pengerjaan perbaikan harus direkam secara detil untuk referensi konservasi yang akan datang. Peran pengelola yang multi stakeholders di Pusat dan daerah lebih optimal untuk saling mengisi. Kesulitan untuk mendapatkan kayu ulin sebagai atap dan tiang, dapat disiasati dengan mengajukan surat permohonan dispensasi kepada pemerintah daerah atau gubernur, sehingga tidak ada alasan untuk tidak ada kayu ulin dan mengganti dengan material lain.

Pelaksanaan pengelolaan rumah adat yang masih lemah, sehingga terjadi benturan kepentingan dan kondisi objek yang kurang optimal, karena adanya benturan antara peraturan yang dibuat oleh pemerintah. UU Cagar Budaya Nomor 11 Tahun 2010 dan Perda Pelestarian dan Pengelolaan Cagar Budaya Nomor 12 Tahun 2012 serta Peraturan Bupati Banjar Nomor 66 Tahun 2012, menyebutkan bahwa pemerintah daerah wajib memelihara cagar budaya. Pada sisi lain, Permendagri Nomor 13 Tahun 2006 menyebutkan bahwa setiap pemeliharaan hanya diperbolehkan untuk aset daerah. Terjadi benturan peraturan karena rumah adat di Teluk Selong masih merupakan aset pribadi (masyarakat) sehingga 
Pemda kesulitan untuk melakukan pemeliharaan. Pemahaman pemangku kepentingan tentang keberadaan bangunan bersejarah yang meliputi fisik bangunan dan lingkungannya, ternyata juga sangat kurang. Peningkatan pemahaman tentang peraturan perundangan dan kebijakan kepada para pejabat di daerah, terutama di lingkungan Dinas Kebudayaan dan Pariwisata, Bappeda, dan Kimpraswil berupa sosialiasi tentang UndangUndang Cagar Budaya. Pemahaman untuk masyarakat diberikan melalui pembuatan leaflet atau brosur yang dapat diambil secara gratis di lokasi wisata rumah adat.

Penyelesaian masalah kepemilikan lahan, perlu dilakukan supaya pengelolaan rumah adat dapat berjalan maksimal. Konflik internal antara juru pelihara dan perangkat desa menyebabkan hubungan yang kurang harmonis, meskipun ahli waris tidak pernah mempermasalahkan rumahnya menjadi cagar budaya.

Strategi Kekuatan - Ancaman (Strength - Threats)

Strategi pengelolaan kawasan rumah adat disusun untuk mendapatkan hasil yang optimal, oleh karena itu perlu menggunakan kekuatan (S) dengan menghindari ancaman ( $\mathrm{T}$ ) yang terdapat di Teluk Selong. Beberapa kekuatan yang ada di kawasan rumah adat Teluk Selong ada yang mendapat ancaman. Arsitektur rumah adat yang unik, estetis, dan adaptif mendapat ancaman dengan adanya organisme berupa koloni jamur dan rayap yang menggerogoti kekuatan rumah kayu. Apabila tidak segera diatasi, maka bangunan rumah adat bisa rusak dan hancur sehingga nilai arkelogis dan nilai historisnya akan hilang. Upaya konservasi bangunan kayu secara rutin akan menjaga keawetan bangunan kayu, sehingga keunikan arsitektur dan kesejarahannya tetap terjaga.

Lingkungan permukiman masyarakat Banjar yang khas tercemar oleh adanya perilaku sosial para pengunjung, terutama anak-anak muda dari luar kampung, yang cenderung negatif. Mereka memanfaatkan halaman yang luas, nyaman, dan sepi untuk beberapa hal yang negatif, seperti pacaran, menenggak minuman keras, ngelem, berkelahi, dan bahkan transaksi narkoba. Peningkatan keamanan dengan membuat pagar berkunci di jalan titian beton (dari belakang) perlu dilakukan, serta penting dijaga oleh satuan tenaga pengaman (satpam). Selain ancaman berupa dampak sosial, dampak fisik yang dapat mengancam keberadaan kawasan rumah adat adalah adanya limbah makanan dan minuman pengunjung yang dibuang sembarangan di kolong rumah dan halaman. Meskipun bak sampah sudah disediakan, tetapi tetap saja ada pengunjung yang tidak taat. Hal tersebut perlu diatasi dengan peraturan, pengawasan perilaku pengunjung, serta sanksi yang tegas terhadap pelanggar.

Strategi Kelemahan - Ancaman (Weaknesses Threats)

Strategi yang terakhir, adalah melaksanakan kegiatan yang bersifat defensif atau mempertahankan yang ditujukan untuk meminimalkan kelemahan (W), serta menghindari ancaman ( $\mathrm{T})$. Kelemahan yang terdapat di kawasan rumah adat Teluk Selong berupa terjadinya perubahan setting kawasan dan penurunan kualitas lingkungan. Hal tersebut akan memperburuk keberadaan kawasan, jika keberadaan rumah kayu terancam hancur karena jamur dan rayap yang tumbuh lebih cepat dari upaya konsevasi. Upaya minimalisasi kelemahan sumber daya tersebut adalah dengan upaya pemeliharaan berupa konservasi dan preservasi (perawatan untuk pencegahan) yang teratur. Pada sisi lain, ancaman karena dampak berupa perilaku sosial dan fisik yang lebih fatal harus dicegah dengan tidak menambah lagi lahan reklamasi untuk keperluan apa pun. Perubahan setting lingkungan yang menyalahi zonasi cagar budaya dan prinsip harmoni lingkungan dikembalikan pada kondisi awal, yaitu dengan membongkar halaman beton diganti dengan halaman dari papan kayu ulin. Kelemahan masih kurangnya sistem pengelolaan dan status lahan harus segera diselesaikan secara tuntas, antara lain dengan peningkatan pengetahuan juru pelihara, peningkatan pemahaman dan koordinasi pemangku kepentingan. 
Matriks 2. Model Strategi Pengelolaan Rumah Adat Banjar Teluk Selong Ulu

\begin{tabular}{|c|c|c|}
\hline & STRENGTHS (S) & WEAKNESSES (W) \\
\hline OPPORTUNITIES (0) & $\begin{array}{l}\quad \text { Strategi S - O } \\
\text { 1. Pemanfaatan untuk wisata budaya } \\
\text { berwawasan lingkungan } \\
\text { 2. Pengelolaan terpadu dan } \\
\text { terkoordinir } \\
\text { 3. Penguatan apresiasi masyarakat } \\
\text { dan unsur budaya lokal } \\
\text { 4. Penataan kawasan permukiman } \\
\text { tradisional }\end{array}$ & $\begin{array}{l}\text { Strategi W - } 0 \\
\text { 1. Perbaikan setting dan ekosistem } \\
\text { yang rusak } \\
\text { 2. Perbaikan bagian rumah yang } \\
\text { rusak sesuai aturan } \\
\text { 3. Peningkatan pemahaman tentang } \\
\text { peraturan perundangan dan } \\
\text { kebijakan } \\
\text { 4. Penyelesaian masalah kepemilikan } \\
\text { lahan dan zonasi }\end{array}$ \\
\hline THREATS (T) & $\begin{array}{l}\quad \text { Strategi S - T } \\
\text { 1. Konservasi secara rutin } \\
\text { 2. Peningkatan keamanan kawasan } \\
\text { 3. Pengaturan dan pengawasan } \\
\text { perilaku pengunjung } \\
\text { 4. Peran aktif koodinator dalam } \\
\text { manajemen konflik }\end{array}$ & \begin{tabular}{l}
\multicolumn{1}{c}{ Strategi $\mathbf{W}$ - T } \\
1. Preservasi dan minimalisasi \\
dampak \\
2. Tidak memperluas lahan reklamasi \\
untuk menjaga perubahan \\
pemaknaan objek
\end{tabular} \\
\hline
\end{tabular}

\section{PENUTUP}

Rumah adat Banjar di Teluk Selong merupakan bangunan cagar budaya yang dikembangkan dan dimanfaatkan menjadi objek kawasan wisata budaya. Berdasarkan penelitian yang telah dilakukan, maka dapat disimpulkan beberapa hal berkaitan dengan pengelolaan kawasan rumah adat sebagai berikut.

1. Dampak kegiatan pengelolaan dan pengembangan kawasan rumah adat Banjar di Teluk Selong terhadap lingkungan sekitar berupa dampak fisik dan sosial. Dampak fisik berupa penurunan kualitas lingkungan, meskipun saat ini belum dirasakan oleh masyarakat sekitar. Dampak sosial yang timbul berupa menurunnya tingkat keamanan, konflik sosial dan perubahan perilaku sosial. Menurunnya tingkat keamanan dan perubahan perilaku sosial karena pengaruh perilaku negatif pengunjung, seperti perkelahian dan mabuk.
Hal tersebut terjadi setelah adanya pembangunan halaman beton sebagai taman dan tempat parkir dengan reklamasi lahan rawa, sehingga mengurangi harmoni lingkungan dan makna kearifan lokal.

2. Model strategi pengelolaan rumah adat Banjar dilakukan dengan optimalisasi kekuatan dan meminimalkan kelemahan untuk memanfaatkan peluang dan mencegah ancaman. Kawasan rumah adat yang kini telah menjadi objek wisata harus dikelola dengan memperhatikan aspek pelestarian sumber daya budaya dan prinsip kearifan lokal. Jika mengacu pada prinsip pelestarian, maka halaman beton tersebut harus dibongkar dan dikembalikan pada kondisi semula. Pembuatan halaman parkir atau taman dilakukan sesuai dengan zonasi lingkungan cagar budaya, dengan menggunakan bahan kayu berbentuk panggung, sehingga keserasian bangunan cagar budaya dan makna kearifan lokal lingkungan rawa tetap terjaga. 


\section{DAFTAR PUSTAKA}

APCCU. 2013. The Workshop for Protection of Cultural Heritage in Martapura 2012. Cultural Heritage Protection Cooperation Office, Asia Pacific Cultural Centre for Unesco (APCCU).

Brannen, Julia.1997. Memadu Metode Penelitian Kualitatif dan Kuantitatif. Samarinda: Fakultas Tarbiyah IAIN Antasari.

Bungin, Burhan editor. 2003. "Menyusun Rancangan Penelitian Kualitatif." dalam Analisis Data Kuantitatif. Jakarta: PT. Raja Grafindo Persada.

Hartatik. 2014. Strategi Pengelolaan Kawasan Rumah Adat Banjar di Teluk Selong Ulu, Kabupaten Banjar: Pendekatan Pelestarian Sumber Daya Arkeologi dan Kearifan Lokal. Tesis. Banjarbaru: Program Studi Pengelolaan Sumber Daya Alam dan Lingkungan, Pascasarjana Universitas Lambung Mangkurat.

Kementerian Kebudayaan dan Pariwisata. 2011. Undang-Undang Republik Indonesia Nomor 11 Tahun 2010 tentang Cagar Budaya. Jakarta : Ditjen Sejarah dan Purbakala, Kementerian Kebudayaan dan Pariwisata.

Lippsmeier, Georg. 1980. Bangunan Tropis (Tropenbau Building in the Tropics). Alih bahasa Syahmir Nasution dan editor oleh Purnomo Wahyu Indarto. Jakarta: Pener.

Moleong, Lexy J. 1989. Metodologi Penelitian Kualitatif. Bandung: Remadja Karya.

Muchamad, Noor Bani dan Ira Mentayani. 2007. Anatomi Rumah Bubungan Tinggi. Banjarmasin: Pustaka Banua.

Mundardjito,. 2008. "Konsep Cultural Resource Management dan Kegiatan Pelestarian Arkeologi di Indonesia." HIm 7-22 dalam Kumpulan Makalah Pertemuan IImiah Arkeologi XI, Solo 13-16 Juni 2008. Jakarta: Ikatan Ahli Arkeologi Indonesia. HIm: 7-22.
Nuryanti, Wiendu. 2005. Pemanfaatan Benda Cagar Budaya dalam Konteks Pariwasata. Buletin Cagar Budaya. No. 4 Mei 2005. Jakarta: Asdep Urusan Kepurbakalaan dan Permuseuman. Departemen Kebudayaan dan Pariwisata, hlm. 19-21.

Raharjo, Supratikno dan Hamdi Muluk. 2011. Pengelolaan Warisan Budaya Indonesia. Jakarta: BPSD Budpar, Kementerian Kebudayaan dan Pariwisata.

Rangkuti, Freddy. 2013. Analisis SWOT. Edisi revisi. Jakarta: Gramedia Pustaka Utama.

Rossle, M dan Cleere, H. 2001. Cultural Landscapes. dalam World Conservation: Vision and Reality. The World Heritage Convention. IUCN, Rue Mauverney 28 $\mathrm{CH}-1196$, Gland- Switzerland.

Saleh, Idwar. 1980/1981. Rumah Tradisional Banjar Rumah Bubungan Tinggi. Banjarbaru: Museum Negeri Lambung Mangkurat Provinsi Kalimantan Selatan.

Saptono, Nanang. 2013. "Pengelolaan Sumber Daya Alam Melalui Sektor Pariwisata di Kawasan Lindung Karangkamulyan, Kabupaten Ciamis, Provinsi Jawa Barat." Tesis. Bandung: Program Studi IImu Lingkungan, Pascasarjana Univesitas Padjadjaran.

Seman, Syamsiar dan Irhamna. 2006. Arsitektur Tradisional Banjar Kalimantan Selatan Banjarmasin: Lembaga Pengkajian dan Pelestarian Budaya Banjar.

Suprayogo, Imam danTobroni, 2003. Metodologi Penelitian Sosial-Agama. Bandung: PT Remaja Rosdakarya.

Tim Penelitian. 2012. "Verifikasi Cagar Budaya di Kecamatan Martapura Kota, Martapura Timur, Martapura Barat, dan Karang Intan Kabupaten Banjar." Disbudparpora Kabupaten Banjar dan Balai Arkeologi Banjarmasin. 


\section{LAMPIRAN}

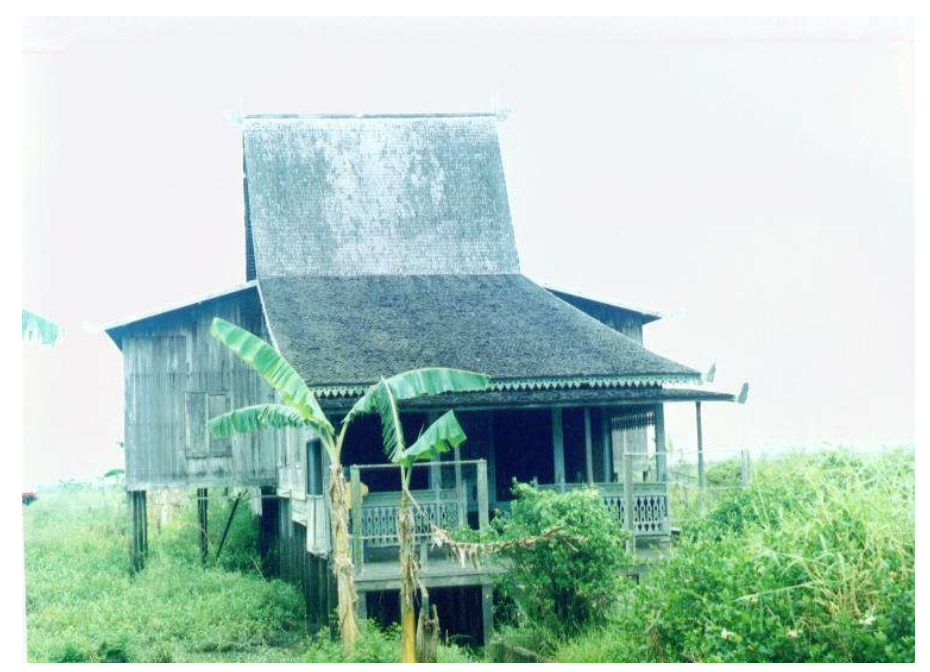

sumber: dok. Balar Banjarmasin

Gambar 2. Rumah adat Bubungan Tinggi pada tahun 2014

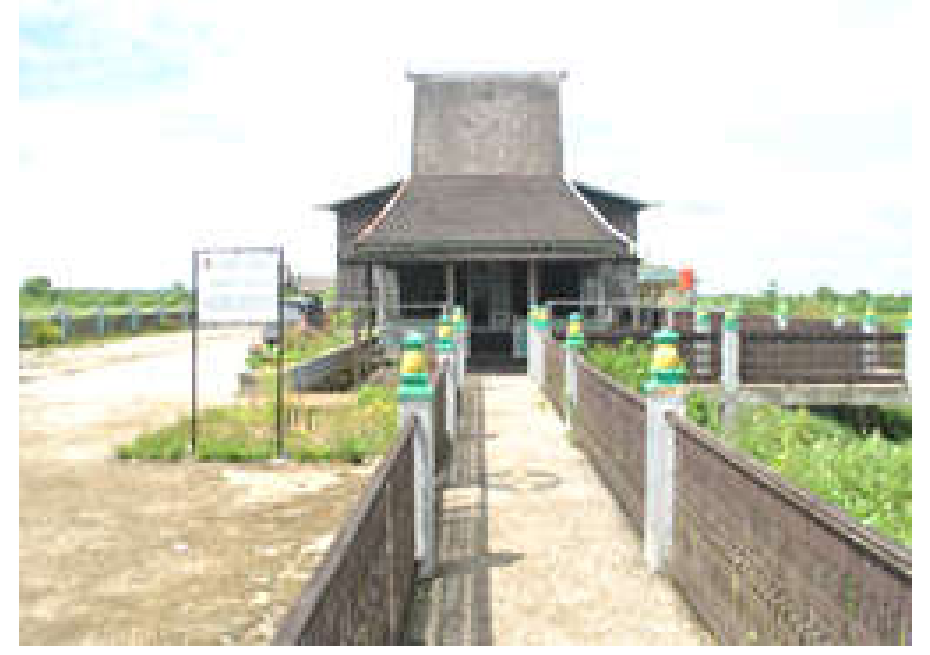

sumber: dok. pribadi

Gambar 3. Foto rumah Bubungan Tinggi tahun 2013 setelah reklamasi halaman

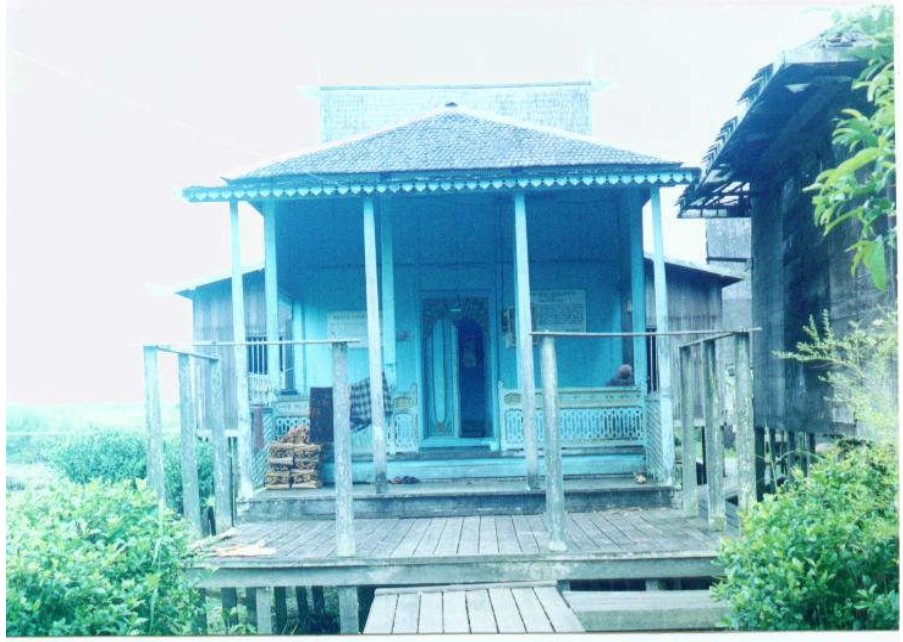

sumber: dok. Balar Banjarmasin

Gambar 4. Rumah adat Adat Gajah Baliku pada tahun 2004 


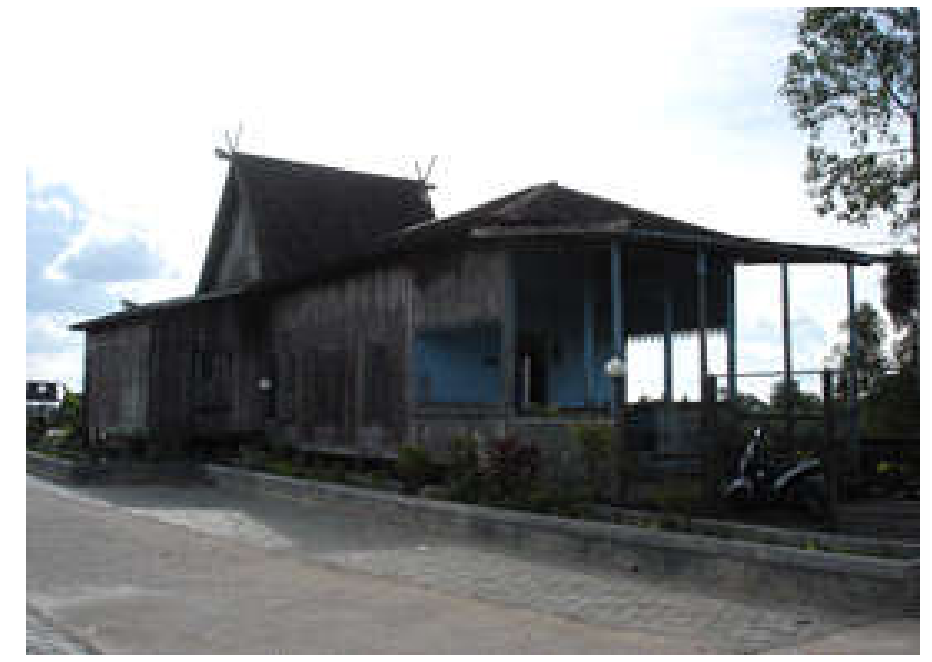

sumber: dok. pribadi

Gambar 5. Lingkungan Rumah Adat Gajah Baliku setelah reklamasi

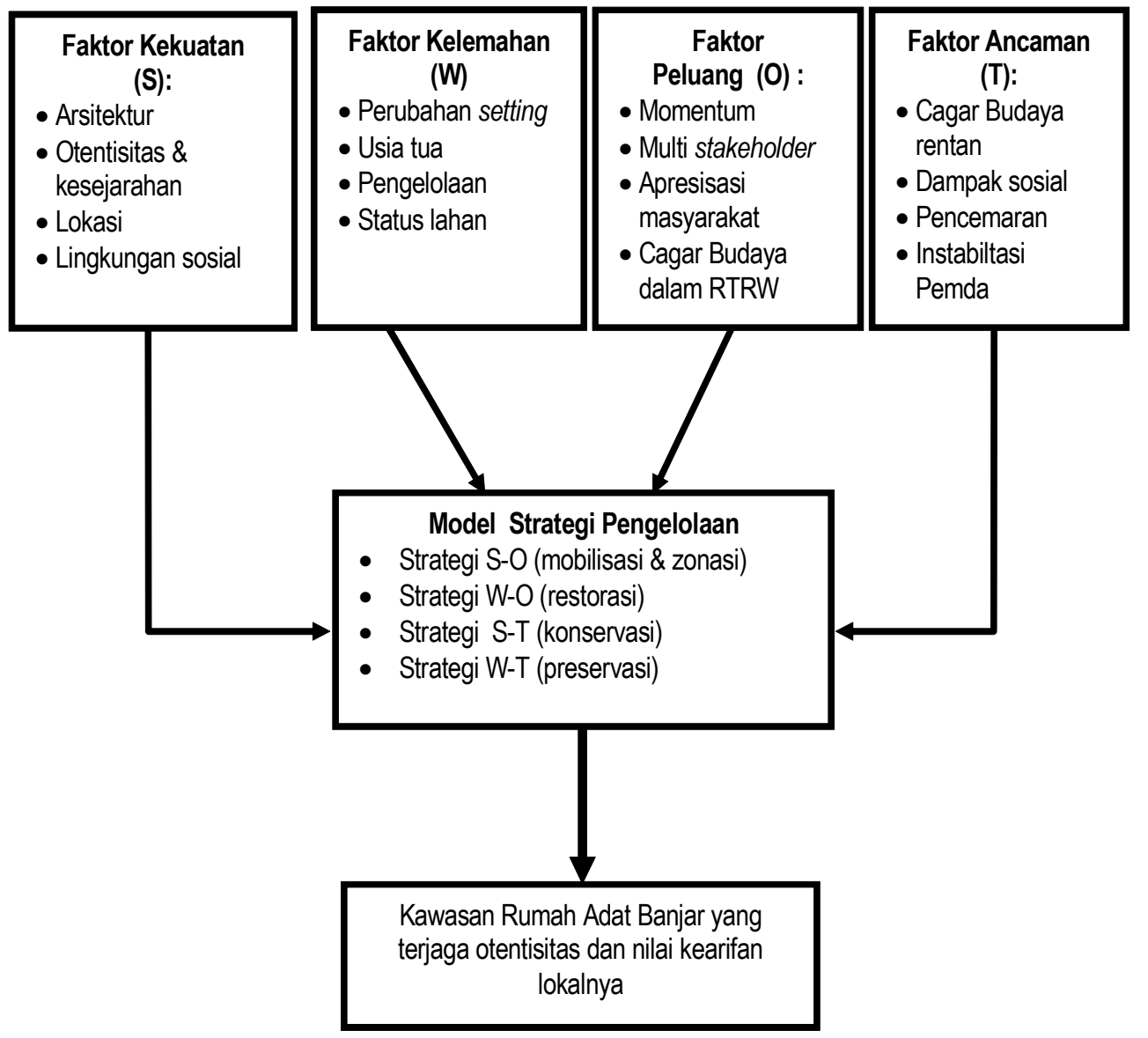

Gambar 6. Bagan Model Strategi Pengelolaan 
Tabel 1. Nama, Fungsi, dan Ukuran Ruang Rumah Adat Bubungan Tinggi

\begin{tabular}{|c|c|c|c|c|}
\hline Bagian & Nama Ruang & Fungsi & $\begin{array}{l}\text { Ukuran } \\
(p \times I) m\end{array}$ & Luas $\left(\mathrm{m}^{2}\right)$ \\
\hline \multirow[t]{3}{*}{ Depan } & $\begin{array}{l}\text { Surambi muka } \\
\text { (terbuka, tanpa atap) }\end{array}$ & $\begin{array}{l}\text { Tempat mencuci kaki sebelum } \\
\text { masuk rumah }\end{array}$ & $1,8 \times 5,82$ & 10,47 \\
\hline & Surambi sambutan (tanpa atap) & $\begin{array}{l}\text { Tempat menyambut tamu } \\
\text { Tempat menjemur hasil pertanian } \\
\text { pada saat air pasang }\end{array}$ & $2,1 \times 5,82$ & 12,22 \\
\hline & $\begin{array}{l}\text { Palatar/Lapangan pamedangan } \\
\text { (beratap dan pagar tatah } \\
\text { kandang rasi) }\end{array}$ & $\begin{array}{l}\text { Tempat santai di sore hari, tempat } \\
\text { menerima tamu dekat }\end{array}$ & $3,52 \times 5,82$ & 20,48 \\
\hline \multirow{5}{*}{$\begin{array}{l}\text { Ruang } \\
\text { Tamu }\end{array}$} & Pacira luar & Ruang transisi, ruang penerima & $1,3 \times 2,04$ & 2,65 \\
\hline & Pacira dalam & Tempat menyimpan peralatan kerja & $\begin{array}{l}(2,78 \times 5,82)- \\
(1,3 \times 2,04)\end{array}$ & 13,52 \\
\hline & Panampik kacil & $\begin{array}{l}\text { Tempat anak-anak saat upacara } \\
\text { Tempat menyimpan hasil panen }\end{array}$ & $\begin{array}{l}(2,78 \times 5,82)- \\
(1,3 \times 2,04)\end{array}$ & 13,52 \\
\hline & Panampik tangah/paluaran & $\begin{array}{l}\text { Ruang tamu, terutama laki-laki } \\
\text { dewasa pada saat upacara }\end{array}$ & $2,15 \times 5,82$ & 12,51 \\
\hline & Panampik basar & $\begin{array}{l}\text { Ruang tamu, terutama tamu } \\
\text { penting/tokoh masyarakat }\end{array}$ & $2,15 \times 5,82$ & 12,51 \\
\hline \multirow{3}{*}{$\begin{array}{l}\text { Ruang } \\
\text { keluarga }\end{array}$} & Paledangan/Panangah & Ruang keluarga & $9,9 \times 5,82$ & 57,61 \\
\hline & Anjung kiri kanan & Ruang tidur, ibadah, berhias & $(5,88 \times 3,76) \times 2$ & 44,21 \\
\hline & Anjung jurai kiri kanan & $\begin{array}{l}\text { Sama dengan anjung kiri } \\
\text { kanan,tempat melahirkan, } \\
\text { memandikan mayat }\end{array}$ & $(4,02 \times 3,76) \times 2$ & 30,23 \\
\hline \multirow{5}{*}{$\begin{array}{l}\text { Ruang } \\
\text { belakang/ } \\
\text { pelaya- } \\
\text { nan }\end{array}$} & $\begin{array}{l}\text { Karawat dan katil } \\
\text { (lantai 2) }\end{array}$ & $\begin{array}{l}\text { Tempat tidur anak sebelum } \\
\text { menikah }\end{array}$ & $9,22 \times 5,82$ & 53,66 \\
\hline & Panampik dalam Ipadu & Ruang saji dan ruang makan & $5,20 \times 5,82$ & 30,26 \\
\hline & Jorong & $\begin{array}{l}\text { Ruang penyimpanan hasil } \\
\text { pertanian }\end{array}$ & $1,90 \times 5,82$ & 11,05 \\
\hline & Padapuran/padu & Tempat memasak & $3,61 \times 5,82$ & 21,01 \\
\hline & Palatar belakang & Tempat mandi, cuci, menjemur & $7,51 \times 3,76$ & 28,23 \\
\hline \multicolumn{4}{|c|}{ LUAS TOTAL } & 374,21 \\
\hline
\end{tabular}

Tabel 2. Nama, Fungsi, dan Ukuran Ruang Rumah Adat Gajah Baliku

\begin{tabular}{|c|c|c|c|c|}
\hline Bagian & Nama Ruang & Fungsi & $\begin{array}{l}\text { Ukuran } \\
(p \times I) m\end{array}$ & Luas $\left(\mathrm{m}^{2}\right)$ \\
\hline \multirow[t]{3}{*}{$\begin{array}{l}\text { Depan/ } \\
\text { teras }\end{array}$} & Surambi muka (terbuka) & $\begin{array}{l}\text { Tempat mencuci kaki sebelum } \\
\text { masuk rumah }\end{array}$ & $4,72 \times 2,62$ & 12,37 \\
\hline & Surambi sambutan (terbuka) & $\begin{array}{l}\text { Tempat menyambut } \\
\text { tamu,tempat menjemur hasil } \\
\text { pertanian pada saat air pasang }\end{array}$ & $1,8 \times 5,82$ & 10,47 \\
\hline & $\begin{array}{l}\text { Palatar atau surambi beratap } \\
\text { dan pagar tatah kandang rasi }\end{array}$ & $\begin{array}{l}\text { Tempat santai di sore hari, } \\
\text { tempat menyambut tamu }\end{array}$ & $2,1 \times 5,82$ & 12,22 \\
\hline Ruang Tamu & $\begin{array}{l}\text { Panampik basar/ambin } \\
\text { sayup }\end{array}$ & Ruang tamu & $4,72 \times 3,35$ & 15,81 \\
\hline \multirow[t]{3}{*}{$\begin{array}{l}\text { Ruang } \\
\text { keluarga }\end{array}$} & Palidangan/ambin sayup & $\begin{array}{l}\text { Ruang keluarga, pertemuan } \\
\text { keluarga }\end{array}$ & $4,72 \times 7,36$ & 34,73 \\
\hline & Anjung kiri kanan & Ruang tidur, ibadah, berhias & $(2,96 \times 7,16) \times 2$ & 42,39 \\
\hline & Anjung tengah & Ruang bersama untuk keluarga & $4,72 \times 7,16$ & 33,79 \\
\hline Bagian & Nama Ruang & Fungsi & $\begin{array}{l}\text { Ukuran } \\
(p \times I) m\end{array}$ & Luas $\left(\mathrm{m}^{2}\right)$ \\
\hline \multirow{4}{*}{$\begin{array}{l}\text { Ruang } \\
\text { belakang }\end{array}$} & & & & \\
\hline & Panampik bawah /padu & Ruang saii dan ruang makan & $4,72 \times 3,16$ & 14,92 \\
\hline & Padapuran & Tempat memasak & $4,72 \times 6,29$ & 29,69 \\
\hline & Palatar belakang & Tempat mandi, cuci, menjemur & $2,96 \times 6,29$ & 18,62 \\
\hline \multicolumn{4}{|l|}{ Luas Total } & 225,01 \\
\hline
\end{tabular}

